\title{
PENINGKATAN KEMAMPUAN MOTORIK HALUS ANAK USIA DINI MELALUI KOLASE BERBAHAN SERBUK KAYU PADA KELOMPOK B DI RA YASBIMAN AL-MUNAWAR KABUPATEN TASIKMALAYA
}

\author{
Wida Nurmala ${ }^{1}$, Yasbiati $^{2}$, Taopik Rahman ${ }^{3}$. \\ ${ }^{1}$ Universitas Pendidikan Indonesia Kampus Tasikmalaya \\ ${ }^{2}$ Universitas Pendidikan Indonesia Kampus Tasikmalaya \\ ${ }^{3}$ Universitas Pendidikan Indonesia Kampus Tasikmalaya
}

Email : opik@upi.edu

(Received: Nopember 2019; Accepted: Nopember 2019; Published: Desember 2019)

\begin{abstract}
Smooth motor skills are abilities that involve muscles in certain parts of body, such as fingers. One of the activities that can improve the fine motor skills of early childhood is through collage activities made from wood powder. This study aims to improve the fine motor skills of early childhood through collections made from wood powder in group B in RA Yasbiman Al-Munawar Tasikmalaya District. The fine motor aspects studied are the motion of both hands, the skill of moving the limbs associated with the fingers, and the skills are able to coordinate the eye by hand. This type of research is Classroom Action Research. The research model from Kemmis and Mc. Taggart. The Data analysis in this study are used qualitative data and quantitative data. Subjects in this study were early childhood group B RA Yasbiman Al-Munawar amounted to 15 people, namely 6 boys and 9 girls. The results of this study showed that the fine motor skills of children have increased after giving them the collage activity of wood powder.
\end{abstract}

Keywords: Early Child, Motorik Smooth, Collage

\begin{abstract}
ABSTRAK
Kemampuan motorik halus adalah kemampuan yang melibatkan otot-otot pada bagian tubuh tertentu seperti jari tangan. Salah satu kegiatan yang dapat meningkatkan kemampuan motorik halus anak usia dini yaitu melalui kegiatan kolase berbahan serbuk kayu. Penelitian ini bertujuan untuk peningkatan kemampuan motorik halus anak usia dini melalui kolase berbahan serbuk kayu pada kelompok B di RA Yasbiman AlMunawar Kabupaten Tasikmalaya. Aspek motorik halus yang diteliti antara lain, keterampilan gerak kedua tangan, keterampilan menggerakan anggota tubuh yang berhubungan dengan jari-jemari, dan keterampilan yang mampu mengkoordinasikan mata dengan tangan. Jenis penelitian ini yaitu Penelitian Tindakan Kelas. Dengan model penelitian Kemmis dan Mc. Taggart. Analisis data dalam penelitian ini peneliti menggunakan data kualitatif dan data kuantitatif. Subjek dalam penelitian ini adalah anak usia dini kelompok B RA Yasbiman Al-Munawar berjumlah 15 orang, yaitu 6 orang anak laki-laki dan 9 orang anak perempuan. Hasil penelitian ini menunjukan bahwa kemampuan motorik halus anak mengalami peningkatan setelah diberikan kegiatan kolase berbahan serbuk kayu.
\end{abstract}

Kata kunci : Anak Usia Dini, Motorik Halus, Kolase 


\section{PENDAHULUAN}

Anak usia dini adalah sekumpulan anak yang sedang mengalami masa pertumbuhan dan perkembangan yang sangat pesat. Berk (dalam Sujiono 2013 hlm. 6) mengemukakan bahwa "pada masa ini proses pertumbuhan dan perkembangan dalam berbagai aspek sedang mengalami masa yang cepat dalam rentang perkembangan hidup manusia".

Anak usia dini merupakan investasi yang sangat besar untuk keluarga, bangsa, dan negara. Anak usia dini adalah penerus di masa depan yang akan menjadi pemimpin di muka bumi ini. Pada masa anak usia dini juga sering disebut dengan masa emas (the golden age) karena pada masa ini pertumbuhan dan perkembangan anak sangat berkembang dengan pesat, baik pertumbuhan kecerdasan, motorik, perkembangan intelektual, sosial emosional, bahasa dan juga seni. Namun, jika kita salah dalam memberikan arahan dan bimbingan maka akan memberikan dampak negatif dalam jangka panjang dan sulit untuk diperbaiki.

Berdasarkan Undang-Undang RI No. 20 Tahun 2013 tentang sistem pendidikan nasional Bab 1 ayat 14 , menyatakan bahwa pendidikan anak usia dini adalah upaya pembinaan yang dutujukan kepada anak sejak lahir sampai usia 6 tahun yang dilakukan dengan pemberian rangsangan pendidikan untuk membantu pertumbuhan dan perkembangan jasmani dan rohani agar anak memiliki kesiapan untuk memasuki pendidikan lebih lanjut.

Salah satu perkembangan yang ada pada pendidikan anak usia dini yaitu perkembangan motorik. Perkembangan motorik adalah pengendalian jasmani yang terpusat pada pusat saraf yang harus terkoordinasi dengan tepat. Perkembangan motorik terbagi menjadi dua bagian yaitu motorik halus dan motorik kasar. Namun pada penelitian ini penulis lebih terfokus pada pembahasan mengenai motorik halus.
Kemampuan motorik halus adalah kemampuan yang melibatkan otot-otot pada bagian tubuh tertentu seperti jari tangan. Kemampuan motorik halus

sangatlah diperlukan dalam kehidupan sehari-hari agar anak mampu melakukan aktivitas disekolah maupun diluar sekolah, seperti mengerjakan tugastugas sekolah, menggunting, mengikat sepatu, mengancingkan baju dan lain sebagainya. Pada intinya tujuan dari perkembangan kemampuan motorik halus adalah anak mampu mengembangkan gerak kedua tangan terutama pada jari jemarinya.

Anak Usia 5-6 tahun diharapkan telah mampu menguasai beberapa kemampuan motorik halus, seperti menggambar sesuai gagasannya, meniru bentuk, melakukan eksplorasi dengan berbagai media dan kegiatan, menggunakan alat tulis dan alat makan dengan benar, menggunting sesuai dengan pola, menempel gambar dengan tepat, dan mengekspresikan diri melalui gerakan menggambar secara rinci (Permendikbud Nomor 137 Tahun 2014).

Menurut hasil observasi dan wawancara, pada kenyataanya di RA Yasbiman Al-Munawar, Desa Cikubang Kecamatan Taraju Kabupaten Tasikmalaya sebagian besar dari jumlah anak kemampuan motorik halus nya masih rendah, saat diberi kegiatan yang berkaitan dengan motorik halus sebagian anak sering meminta bantuan guru untuk menyelesaikan pekerjaannya dan selalu berkata "ibu saya tidak bisa", anak-anak juga masih kurang terampil dalam menggunakan jari-jari tangan untuk melakukan kegiatan yang agak rumit misalnya saat mengancingkan baju dan mengikat tali sepatu, bahkan masih ada posisi jari-jari anak ketika memegang pensil masih belum benar. Selama ini guru lebih sering mengembangkan motorik halus anak dalam hal mewarnai, menggambar, melipat dan menulis, selain itu pembelajaran di RA Yasbiman Al- 
Munawar lebih terfokus pada pembelajaran agama misalnya membaca iqro, hafalan surat, dan hafalan doa-doa.

Berdasarkan permasalahan di atas maka penulis mempunyai alternatif untuk melakukan penelitian tindakan kelas (PTK) yaitu peningkatan kemampuan motorik halus melalui kolase berbahan serbuk kayu. Kegiatan kolase termasuk ke dalam salah satu kegiatan yang ada di pendidikan anak usia dini yang berkaitan dengan motorik halus. Melalui kolase dengan serbuk kayu, anak dilatih menggerakan jari-jari tangan dan memfokuskan pandangan pada saat menempel. Selain itu anak memiliki rasa peduli terhadap lingkungan sekitar dalam memanfaatkan bahan yang sudah tidak di pakai menjadi suatu hasil karya yang indah. Hal ini juga diperkuat dengan penelitian skripsi Nur Halimah yang berjudul Peningkatan Kemampuan Motorik Halus Anak Usia Dini Melalui Kegiatan Kolase Dengan Berbagai Media Pada Anak Kelompok B3 di TK Aba Ngoro-oro Patuk Gunungkidul Tahun 2016.

Menurut Hajar Pamadhi dan Evan Sukardi dalam Devi (2014 hlm.19) Kolase merupakan suatu karya seni dua dimensi yang menggunakan berbagai macam bahan-bahan selama bahan dasar itu dapat dipadukan dengan bahan dasar lain yang akhirnya dapat menyatu dan menjadi karya yang utuh dan dapat mewakili ungkapan perasaan estetis yang membuatnya. Serbuk kayu merupakan limbah dari serpihan kayu yang berasal dari industri kayu yang belum termanfaatkan dengan baik. Agar limbah dapat termanfaatkan dengan baik maka dapat dijadikan suatu media alternatif untuk meningkatkan kemampuan motorik halus anak melalui kolase berbahan serbuk kayu.

Berangkat dari pemikiran di atas, peneliti terdorong untuk melakukan penelitian mengenai perkembangan motorik halus anak melalui kolase berbahan serbuk kayu di Kelompok B RA Yasbiman Almunawar. Sebagai bahan penulisan skripsi.

\section{TINJAUAN PUSTAKA}

Menurut Sujiono (2012, Hlm. 6) "Anak usia dini a dalah sosok individu yang sedang menjlani suatu proses perkembangan dengan pesat dan fundamental bagi kehidupan selanjutnya". Sedangkan menurut Santoso (dalam Indraswari $2007 \mathrm{Hlm}$. 2) mengemukakan bahwa 'anak usia dini adalah sosok individu sebagai makhluk sosiokultural yang sedang mengalami proses perkembangan yang sangat fundamental bagi kehidupan selanjutnya dan memiliki sejumlah karakteristik tertentu'.

Sedangkan Menurut Solehudin (dalam Mahardika 2017, hlm. 4) mengidentifikasikan sejumlah karakteristik anak usia prasekolah adalah sebagai berikut : Anak bersifat unik, anak mengekspresikan perilakunya secara relatif dan spontan. Anak juga bersifat aktif dan energik. Anak itu egosentris. Anak juga memiliki rasa ingin tahu yang kuat dan autisias terhadap banyak hal. Anak bersifat eksploratif dan petualang. Anak umumnya kaya dengan fantasi. Anak juga masih udah frustasi. Anak masih kurang pertimbangan dalam melakukan sesuatu. Anak memiliki daya perhatian yang pendek. Anak merupakan usia belajar yang potensial. Anak semakin menunjukan minat terhadap teman.

Menurut Santrock (dalam Soetjiningsih 2012, Hlm.2) mengemukakan bahwa 'perkembangan adalah pola perubahan yang dimulai sejak pembuahan dan terus berlanjut di sepanjang rentang kehidupan individu'.Senada dengan Santrock, Hurlock (dalam Soetjiningsih 2012, Hlm.2) mengemukakan bahwa 'perkembangan merupakan serangkaian perubahan progresif yang terjadi sebagai akibat dari proseskema tangan dan pengalaman/belajar. 
Peraturan mentri pendidikan dan kebudayaan republik indonesia nomor 137 tahun $2014 \mathrm{Bab} 1$ ayat 2 mengemukakan bahwa "standar tingkat pencapaian perkembangan anak usia dini selanjutnya disebut STPPA adalah kriteria tentang kemampuan yang di capai anak pada seluruh aspek perkembangan dan pertumbuhan, mencakup aspek nilai agama dan moral, fisik-motorik, kognitif, bahasa, sosialemosiaonal, serta seni".

Hurlock (dalam Mulyati 2014, Hlm. 26) pekembangan motorik adalah perkembangan gerakan jasmaniah dengan melalui kegiatan pusat syaraf, urat syaraf, dan otot yang terkoordinasi. Sedangkan menurut Corbin (dalam Ms Sumantri 2005, Hlm. 48) berpendapat bahwa perkembangan motorik adalah perbahan kemampuan gerak dari bayi sampai dewasa yang melibatkan berbagai aspek prilaku dan kemampuan gerak. Perkembangan motorik meliputi perkembangan otot kasar atau gross muscle dan otot halus atau fine muscle yang sekarang umumnya disebut motorik kasar dan motorik halus Slamet Syuanto (dalam Mulyati 2014, Hlm. 27). Otot besar atau otot kasar merupakan otot-otot besar yang tersusun dari otot lurik, otot ini berfungsi untuk melakukan gerakangerakan yang dasar seperti berjalan, melompat, berlari, melempar, menaiki, dan mendaki. Sedangkan otot halus terjadi karena adanya koordinasi antara mata dan tangan yang berfungdi untuk melakukan gerakan tubuh tertentu yang spesifik misalnya, menulis, menggenggam, meremas, melipat dan memengang (Mulyati, 2014. Hlm 27).

Sujiono (dalam Kartini 2016, Hlm. 5) berpendapat bahwa motorik halus adalah gerakan yang hanya melibatkan otot-otot kecil, seperti jari jemari dan gerakan pergelangan tangan dengan cepat dan tepat. Gerakan motorik halus ini tidak perlu menggunakan tenaga yang banyak melainkan hanya koordinasi mata dan tangan yang baik. Dalam melakukan kegiatan motorik halus, anak juga perlu dukungan Kemampuan fisik serta kematangan mental.

Menurut Sumantri (dalam Mahardika 2017, hlm 1) mengemukakan bahwa 'motorik halus adalah pengorganisasian penggunaan sekelompok otot-otot kecil seperti jarijemari dan tangan yang sering membutuhkan kecermatan dan koordinasi dengan tangan, Kemampuan yang mencakup pemanfaatan menggunakan alat-alat untuk mengerjakan suatu objek. Hal tersebut dikemukakan juga oleh Yudha dan Rudyanto (dalam Mahardika 2017, Hlm 1) bahwa motorik halus adalah kemampuan untuk beraktivitas dengan menggunakan otot halus (kecil) seperti menulis, meremas, menggunting, menggambar, menyusun balok dan memasukan kelereng.

Sumantri (2005, Hlm. 146) mengemukakan bahwa tujuan pengembangan motorik halus adalah :a. Mampu mengembangkan kemampuan motorik halus yang berhubungan dengan keterampilan gerak kedua tangan. b.Mampu menggerakan anggota tubuh yang berhubungan dengan gerak jari-jemari seperti : kesiapan menulis, menggambar, dan memanipulasi bendabenda. c.Mampu mengkoordinasikan indera mata dengan aktivitas tangan. d.Mampu mengendalikan emosi dalam beraktivitas motorik halus.

Kolase berasal dari Bahasa Perancis (collage) yang berarti merekat. 
Kolase adalah aplikasi yang dibuat dengan menggabungkan teknik melukis (lukisan tangan) dengan menempelkan bahan-bahan tertentu sesuai dengan kebutuhan. Sumanto (dalam Devi, 2014 hlm. 41). Sedangkan menurut Hajar Pamadhi dan Evan Sukardi (dalam Devi 2014, hlm. 41) "Kolase merupakan karya seni rupa dua dimensi yang menggunakan bahan yang bermacammacam selama bahan dasar tersebut dapat dipadukan dengan bahan dasar lain yang akhirnya dapat menyatu menjadi karya yang utuh dan dapat mewakili ungkapan perasaan estetis orang yang membuatnya". Menurut Rahmawati (dalam Simatupang dan Ema 2015 hlm. 4) menyebutkan bahwa "Kolase adalah gambar yang dibentuk dari kegiatan menyusun kain, kapas, kulit telur, kertas atau media lainnya yang ditempelkan pada bidang gambar”.

Menurut departemen pertanian 1970 serbuk kayu merupakan limbah industri penggergajian kayu. Selama ini limbah kayu banyak menimbulkan masalah dalam penangananya yang selama ini dibiarkan membusuk, ditumpuk, dan dibakar yang dapat mencemari udara.Semuanya berdampak nengatif terhadap lingkungan sehingga penanggulangannya perlu di pikirkan. Sedangkan menurut Anonimous (dalam Ndraha 2013 hlm. 21) menyebutkan bahwa serbuk kayu merupakan salah satu limbah industri pengolahan kayu seperti serbuk gergajian, sebetan, dan sisa kupasan. Serbuk gergaji merupakan salah satu jenis limbah industri pengolahan kayu gergajian (Pari dalam Ndraha 2009 hlm. 21).

\section{METODE}

Desain penelitian yang dilakukan yaitu Penelitian Tindakan Kelas (PTK).
Menurut (Trianto, 2011, hal. 13) "penelitian tindakan kelas berasal dari istilah bahasa inggris Classroom Action Research, yang berarti penelitian yang dilakukan pada sebuah kelas untuk mengetahui akibat tindakan yang diterapkan pada subjek penelitian di kelas tersebut". Desain model penelitian diambil dari model Kemmis dan Mc. Taggart.

Data adalah bahan mentah yang harus di olah dan menghasilkan suatu informasi, fakta yang akurat. Jenis data terbagi menjadi dua yaitu kualitatif dan kuantitatif. Dalam penelitian ini, peneliti menggunakan data kualitatif dan data kuantitatif. Data yang diperoleh yaitu data kualitatif dan kuantitatif.

Menurut Dimayati (2013) dalam Fauziyah (2017, hlm.40) sumber data ialah 'subjek penelitian dimana darinya akan diperoleh data.' Adapun sumber data dalam penelitian ini adalah : $\mathrm{RPPH}$ ( Rancangan Pelaksanaan Pembelajaran Harian), Guru, dan Anak Usia Dini di Kelompok B RA Yasbiman Al-Munawar.

Teknik pengumpulan data yang digunakan dalam penelitian ini yaitu : Observasi, Catatan Lapangan, Wawancara, Tes Kinerja, Dokumentasi.

Menurut Sugiyono (2015, hlm. 147) analisis data merupakan kegiatan setelah data atau sumber data lain terkumpul. Kegiatan dalam analisis data adalah : mengelompokan data berdasarkan jenis variabel dan responden, mentabulasi data berdasarkan variabel dari seluruh responden, menyajikan data dari tiap variabel yang diteliti, melakukan perhitungan untuk menjawab rumusan masalah.Teknik analisis data yang digunakan dalam penelitian ini adalah teknik analisis deskriptif kuantitatif. Adapun tata cara penghitungan skor melalui instrumen chek list dan LKA (Lembar Kerja Anak) mengenai kemampuan motorik halus anak usia dini melalui kolase berbahan serbuk kayu. 
Adapun rumus penghitungan persentase yang diperoleh adalah sebagai berikut :

$$
\mathrm{NP}=\frac{R}{S M} \mathrm{X} 100 \%
$$

Keterangan : NP $=$ Nilai persen yang dicari atau diharapkan, $\mathrm{R}=$ Skor mentah yang diperoleh, $\mathrm{SM}=$ Skor maksimal ideal dari tes yang bersangkutan, $100=$ Bilangan tetap.

Sedangkan untuk menilai kemampuan guru dalam merencanakan pembelajaran, pelaksanaan pembelajaran, serta kegiatan peningkatan kemampuan motorik halus anak, peneliti menggunakan penilaian yang sama dengan penilaian anak, yaitu diadaptasi oleh Djamarah dan Zain.

\section{HASIL DAN PEMBAHASAN}

Penelitian tindakan kelas yang telah dilaksanakan terdiri dari tiga siklus. Pelaksanaan pada siklus I berlangsung pada tanggal 9 April 2018, pelaksanaan pada siklus II pada tanggal 23 April 2018, dan pelaksanaan siklus III pada tanggal 30 April 2018. Penelitian ini yaitu kegiatan kolase berbahan serbuk kayu untuk meningkatkan kemampuan motorik halus anak usia dini pada kelompok B di RA Yasbiman Al-Munawar Kabupaten Tasikmalaya.

\subsection{Kemampuan Guru dalam Merencanakan Pembelajaran}

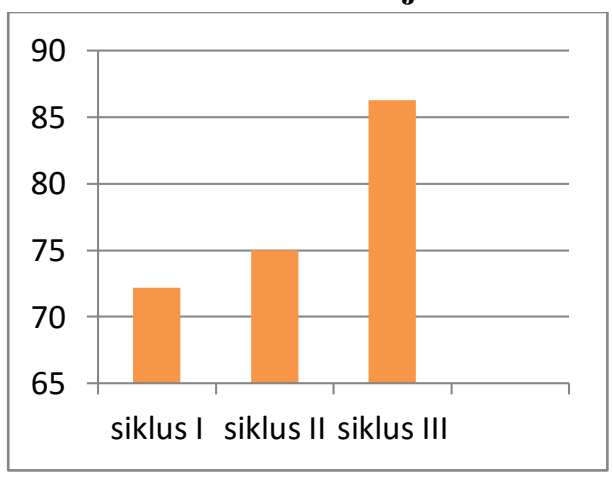

Gambar 4.1

Diagram Perubahan Siklus I - Siklus III Kemampuan Guru dalam Perencanaan Pembelajaran

Kemampuan guru dalam merencanakan pembelajaran pada penelitian tindakan kelas (PTK) ini dituangkan dalam tiga buah rencana pelaksanaan pembelajaran harian (RPPH). Pada tiga siklus tindakan, peningkatan kemampuan guru dalam merencanakan pembelajaran harian adalah sebagai berikut : pada siklus I jumlah skor yang diperoleh guru dalam membuat perencanaan pembelajaran harian adalah 11,55 dengan persentase $72,18 \%$ jumlah tersebut belum mencapai indikator keberhasilan yang telah ditentukan. Kelemahan pada perencanaan pembelajaran harian pada siklus I yaitu pengembangan tema/sub tema dan penentuan metode yang dipilih kurang tepat sehingga berpengaruh terhadap proses pembelajaran. Pada siklus II mengalami peningkatan sebesar 0,55 dengan persentase $2,82 \%$ umlah skor menjadi 12 dengan persentase $75 \%$. Kelemahan pada siklus II yaitu pada penetuan format penilaian proses pembelajaran. Pada siklus III kekurangan tersebut dapat diatasi dan mengalami peningkatan sebesar 1,8 dengan persentase $11,25 \%$ jadi pada siklus III jumlah skor menjadi 13,8 dengan persentase $86,25 \%$. Jadi peningkatan tertinggi terdapat pada siklus II ke siklus III yaitu sebesar 1,8 dengan persentase $11,25 \%$. Hal ini terjadi karena pada siklu III upaya guru dalam memperbaiki Rencana Pelaksanaan Pembelajaran Harian dilakukan dengan optimal.

\subsection{Kemampuan Guru dalam Proses Pembelajaran}

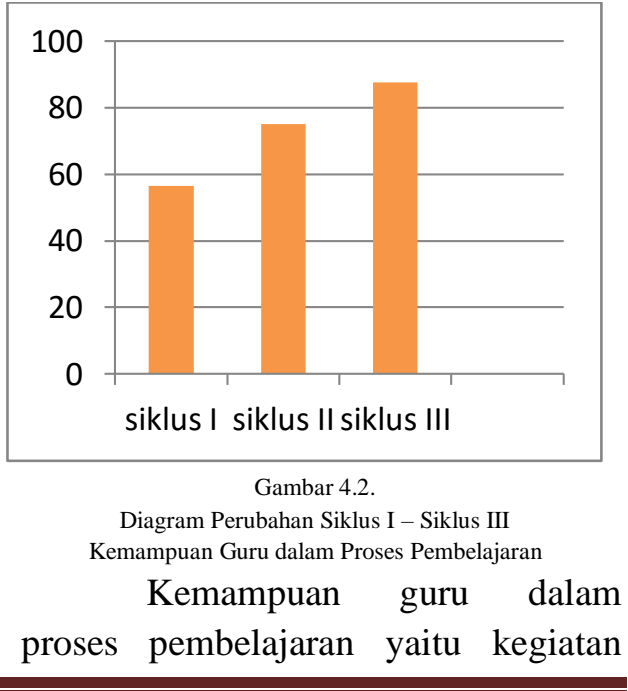


kolase berbahan serbuk kayu untuk meningkatkan kemampuan motorik halus anak usia dini. Kemampuan peneliti dalam melaksanakan kegiatan pembelajaran pada siklus I mencapai 6,8 dengan persentase $56,5 \%$. Ada beberapa aspek yang harus diperbaiki yaitu : a. Memeriksa kesiapan siswa, b. Melakukan kegiatan apresiasi, c. Penguasaan materi pembelajaran, d. Pendekatan/strategi pembelajaran, e. Pemanfaatan ssumber belajar/media pembelajaran, f. Pembelajaran yang memicu dan memelihara keterlibatan siswa, g. Penilaian proses dan hasil belajar, h. Melakukan refleksi dengan melibatkan siswa, i. Melaksanakan tindak lanjut dengan memberikan arahan. Pada siklus II kelemahankelemahan peneliti mulai diperbaiki, dan kemampuan melaksanakan kegiatan mengalami peningkatan sebesar 2,3 dengan persentase 18,5\%, menjadi 9,1 dengan presentase $75 \%$. Pada siklus II sudah mencapai tingkat pencapaian namun penelitian masih tetapi dilanjutkan pada ssiklus III karena kemampuan motorik halus anak masih belum berkembang. Pada siklus III kelemahan-kelemahan sudah diperbaiki, kemampuan melaksanakan kegiatan pembelajaran mengalami peningkatan sebesar 1,4 dengan persentase $12,5 \%$ sehingga jumlah skor pada siklus III menjadi 10,5 dengan persentase $87,5 \%$. Sehingga dapat dinyatakan bahwa peningkatan kemampuan melaksanakan pembelajaran tertinggi yaitu siklus II ke siklus III mengalami peningkatan sebesar 2,3 dengan persentase 18,5\%.
4.3 Kemampuan Guru dalam Meningkatkan Kemapuan Motorik Halus Anak melalui Kolase Berbahan Serbuk Kayu

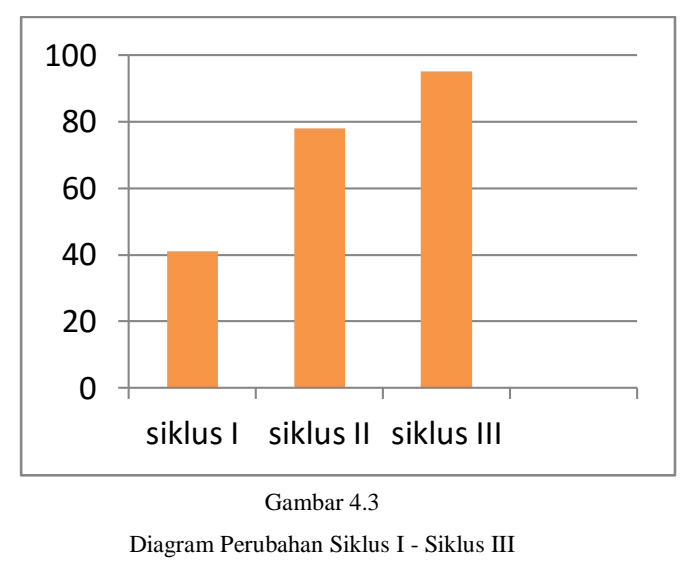

Kemampuan Guru dalam Peningkatan Kemampuan Motorik Halus Anak Usia Dini melalui Kolase Berbahan Serbuk Kayu

Dalam kemampuan guru dalam meningkatkan kemampuan motorik halus melalui kolase berbahan serbuk kayu pada siklus I sebesar 31 dengan persentase $41 \%$ masih terdapat banyak kekurangan dan masih perlu di perbaiki di siklus II. Pada siklus II kelemahan kemampuan guru mulai diperbaiki, dan mengalami peningkatan sebesar 28 dengan persentase $37 \%$ sehingga jumlah skor pada siklus II menjadi 59 dengan persentase $78 \%$. Pada siklus III mengalami peningkatan sebesar 13 dengan persentase 17\% sehingga jumlah skor pada siklus III menjadi 72 dengan persentase $95 \%$. Mampak bahwa meningkatan guru dalam peningkatan motorik halus anak melalui kolase berbahan serbuk kayu dengan gain (rentang) tertinggi adalah siklus I ke siklus II yaitu mengalami peningkatan sebesar 28 dengan persentae $37 \%$.

\subsection{Peningkatan Kemampuan Motorik} Halus Anak Usia Dini

Kemampuan motorik halus anak usia dini dari kondisi awal sampai siklus III mengalami peningkatan

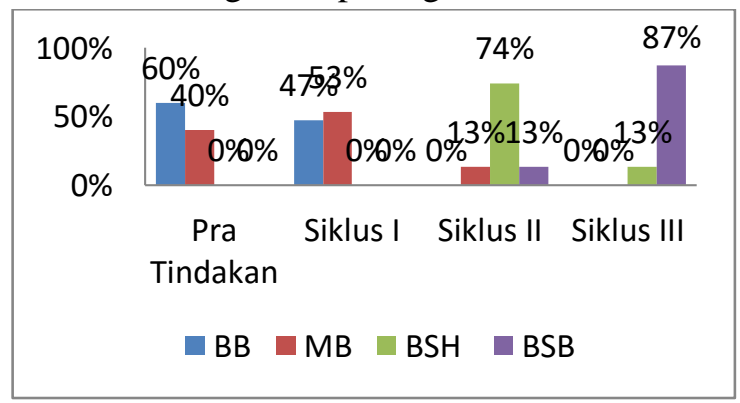

Gambar 4.4. 
Diagram Perubahan Pra Tindakan - Siklus III

Aspek Terampil Menggunakan Tangan Kanan dan Kiri untuk

Melakukan Aktivitas

Dari diagram 4.1. dapat diketahui kriteria BB (Belum berkembang) pada kondisi awal sebesar 60\% (9 orang anak), sedangkan pada siklus I sebesar 47\% (7 orang anak), pada siklus II dan III tidak ada satupun kriteria BB (Belum berkembang). Kriteria MB (Masih berkembang) pada kondisi awal sebesar $40 \%$ (6 orang anak), sedangkan pada siklus I sebesar 30\% (7 orang anak), pada siklus II sebesar 13\% (2 orang anak), dan pada siklus III tidak ada satupun aspek MB (Masih berkembang). Kriteria BSH (Berkembang sesuai harapan) tidak ada satupun pada kondisi awal dan siklus I, siklus II sebesar 74\% (11 orang anak), dan pada siklus III sebesar 13\% (2 orang anak). pada kondisi awal, dan siklus I tidak ada satupun kriteria BSB (Berkembang sangat baik), pada siklus II sebesar 13\% (2 orang anak), dan pada siklus III sebesar 87\% (13 orang anak). dari data tersebut terlihat bahwa kemampuan motorik halus anak usia dini pada aspek terampil menggunakan tangan kanan dan kiri untuk melakukan aktivitas mengalami peningkatan. Hal tersebut terlihat dari perubahan tiap kriteria, dari BB (Belum berkembang) sebagian berpindah menjadi MB (Masih berkembang) meskipun masih ada anak yang kriteria BB (Belum berkembang), dari MB (Masih berkembang) berpindah menjadi BSH (Berkembang sesuai harapan) meskipun masih ada anak yang kriteria MB (Masih berkembang), kriteria BSH (Berkembang sesuai harapan) berpindah menjadi BSB (berkembang sesuai harapan) sehingga pada siklus III semua anak sudah mencapai kriteria BSH (Berkembang sesuai harapan) dan BSB (Berkembang sangat baik).

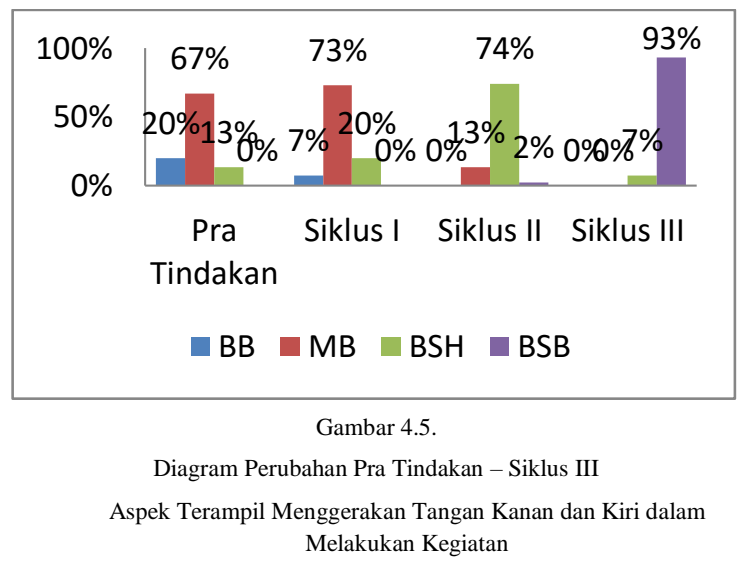

Dari gambar 4.2. dapat diketahui kriteria BB (Belum berkembang) pada kondisi awal sebesar 20\% (3 orang anak), pada siklus II sebesar 7\% (1 orang anak), pada siklus II dan siklus III tidak ada satupun kriteria BB (Belum berkembang). Kriteria MB (Masih berkembang) pada kondisi awal ssebesar 67\% (10 orang anak), siklus I sebesar $73 \%$ (11 orang anak), siklus II sebesar 13\% (2 orang anak), dan pada siklus III tidak ada satupun kriteria MB (Masih berkembang. Kriteria BSH (Berkembang sesuai harapan) pada kondisi awal sebesar 13\% (2 orang anak) siklus I sebesar $20 \%$ (3 orang anak), siklus II sebesar $74 \%$ (11 orang anak), dan siklus III sebesar 7\% (1 orang anak). kriteria BSB (Berkembang sangat baik) pada kondisi awal dan siklus I tidak ada satupun kriteria BSB (Berkembang sangat baik), pada siklus II sebesar 13\% (2 orang anak), dan pada siklus III sebesar 93\% (14 orang anak). Dari data tersebut kemampuan motorik halus anak dalam aspek terampil menggerakan tangan kanan dan kiri dalam melakukan kegiatan mengalami peningkatan. Hal tersebut terlihat dari perubahan tiap kriteria, dari BB (Belum berkembang) sebagian berpindah menjadi MB (Masih berkembang) meskipun masih ada anak yang kriteria BB (Belum berkembang), dari MB (Masih berkembang) berpindah menjadi BSH (Berkembang sesuai harapan), kriteria BSH (Berkembang sesuai harapan) berpindah menjadi BSB (berkembang sesuai harapan) sehingga pada siklus III semua anak sudah mencapai 
kriteria BSH (Berkembang sesuai harapan)

dan BSB (Berkembang sangat baik).

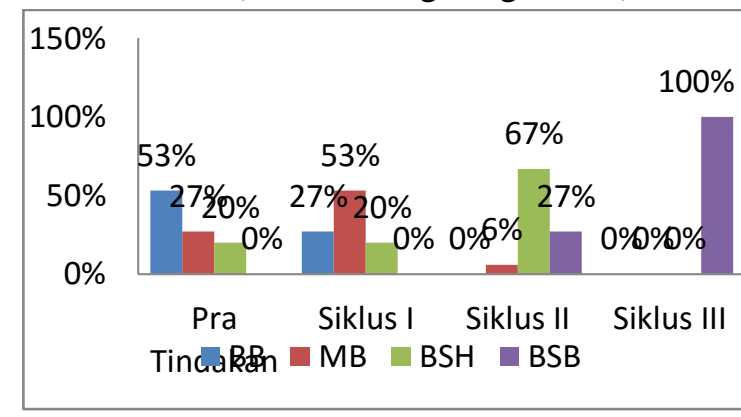

Gambar 4.6.

Diagram Perubahan Pra Tindakan - Siklus III

Aspek Terampil Menggerakan Jari-Jari Tangan dalam Melakukan Aktivitas

Dari gambar 4.3. dapat diketahui kriteria BB (Belum berkembang) pada kondisi awal sebesar 53\% (8 orang anak), siklus I sebesar $27 \%$ (4 orang anak), siklus II dan siklus III tidak ada satupun kriteria BB (Belum berkembang). Kriteria MB (Masih berkembang) pada kondisi awal sebesar $27 \%$ (4 orang anak), siklus I sebesar 53\% (8 orang anak), siklus II sebesar 6\% (1 orang anak), dan pada siklus III tidak ada satupun kriteria MB (Masih berkembang). Kriteria BSH (Berkembang sesuai harapan) pada kondisi awal sebesar $20 \%$ (3 orang anak), siklus I sebesar 20\% (3 orang anak), siklus II sebesar 67\% (10 orang anak), dan siklus III tidak ada satupun kriteria BSH ( Berkembang sesuai harapan). Kriteria BSB (Berkembang sangat baik) pada kondisi awal dan siklus I tidak ada satupun kriteria BSB (Berkembang sangat baik), siklus II sebesar 27\% (4 orang anak), dan siklus III sebesar $100 \%$ (15 orang anak). Dari data tersebut kemampuan motorik halus anak usia dini pada aspek terampil menggerakan jari-jari tangan dalam melakukan aktivitas mengalami peningkatan. Hal tersebut terlihat dari perubahan tiap kriteria, dari BB (Belum berkembang) sebagian berpindah menjadi MB (Masih berkembang) meskipun masih ada anak yang kriteria BB (Belum berkembang), dari MB (Masih berkembang) berpindah menjadi BSH (Berkembang sesuai harapan), kriteria BSH (Berkembang sesuai harapan) berpindah menjadi BSB (berkembang sesuai harapan) sehingga pada siklus III semua anak sudah mencapai kriteria BSB (Berkembang sangat Baik).

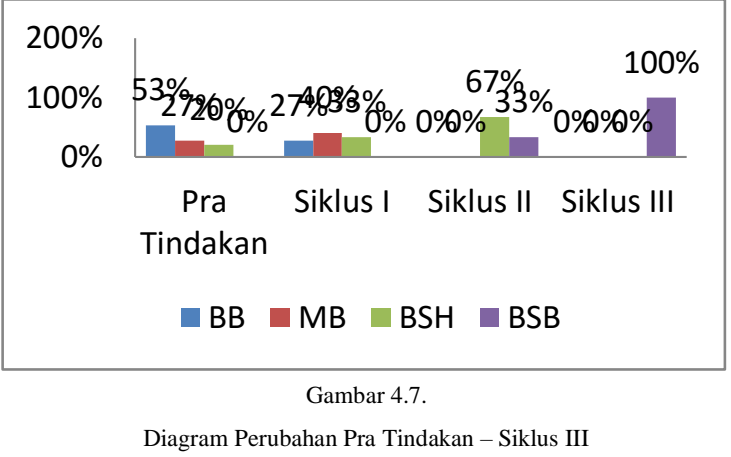

Terampil Dalam Kelenturan Jari-Jari Tangan dalam Melakukan Aktivitas

Dari gambar 4.4. dapat diketahui kriteria BB (belum berkembang) pada kondisi awal sebesar 53\% (8 orang anak) siklus I sebesar 27\% (4 orang anak), siklus II dan siklus III tidak ada satupun kriteria BB (Belum berkembang). Kriteria MB (Mulai berkembang) pada kondisi awal sebesar $27 \%$ (4 orang anak), siklus I sebesar $40 \%$ (6 orang anak), siklus II dan III tidak ada satupun kriteria MB (Masih berkembang), kriteria BSH (Berkembang sesuai harapan) pada kondisi awal sebesar $20 \%$ (3 orang anak), siklus I sebesar 33\% (5 orang anak), siklus II sebesar 67\% ( 10 orang anak), dan pada siklus III tidak ada satupun kriteria BSH (Berkembang sesuai harapan). Kriteria BSB (Berkembang sangat baik) pada kondisi awal dan siklus I tidak ada satupun kriteria BSB (Berkembang sangat baik), siklus II sebesar 33\% (5 orang anak), dan siklus III sebesar $100 \%$ (15 orang anak). Dari data tersebut kemampuan motorik halus anak usia dini pada aspek terampil menggerakan jari-jari tangan dalam melakukan aktivitas mengalami peningkatan. Hal tersebut terlihat dari perubahan tiap kriteria, dari BB (Belum berkembang) sebagian berpindah menjadi MB (Masih berkembang) meskipun masih ada anak yang kriteria BB (Belum berkembang), dari MB (Masih berkembang) berpindah menjadi BSH (Berkembang sesuai harapan), kriteria BSH (Berkembang sesuai harapan) berpindah menjadi BSB (berkembang sesuai harapan) sehingga 
pada siklus III semua anak sudah mencapai kriteria BSB (Berkembang sangat Baik).

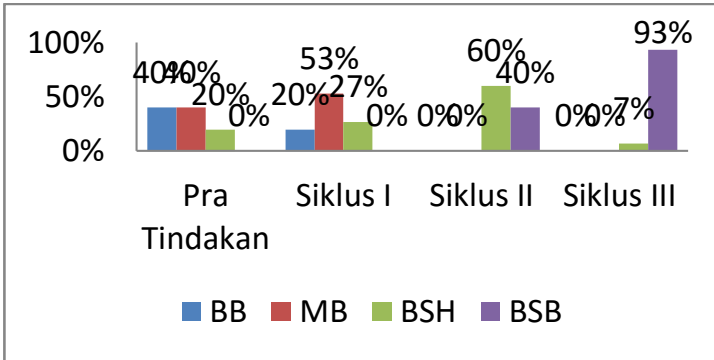

Gambar 4.8.

Diagram Perubahan Pra Tindakan - Siklus III

Aspek Melakukan gerakan terkoordinasi secara terkontrol

Dari gambar 4.5. dapat diketahu kriteria BB (belum berkembang) pada kondisi awal sebesar 40\% (6 orang anak), siklus I sebesar $20 \%$ ( 3 orang anak), siklus II dan III tidak ada ssatupun kriteria BB (Belum berkembang). Kriteria MB pada kondisi awal sebesar 40\% (6 orang anak), siklus I sebesar 53\% (8 orang anak), siklus II dan III tidak ada satupun kriteria MB (Masih berkembang). Kriteria BSH (berkembang sesuai harapan) pada kondisi awal sebesar 20\% (3 orang anak), siklus I sebesar $27 \%$ (4 orang anak), siklus II sebesar $60 \%$ (9 orang anak), dan siklus III sebesar 7\% (1 orang anak). kriteria BSB (Berkembang sangat baik) pada kondisi awal dan siklus I tidak ada satupun kriteria BSB (Berkembang sangat baik), siklus II sebesar 40\% (6 orang anak), dan siklus III sebesar 93\% (14 orang anak). Dari data tersebut kemampuan motorik halus anak usia dini pada aspek melakukan gerakan terkoordinasi secara terkontrol mengalami peningkatan. Hal tersebut terlihat dari perubahan tiap kriteria, dari BB (Belum berkembang) sebagian berpindah menjadi MB (Masih berkembang) meskipun masih ada anak yang kriteria BB (Belum berkembang), dari MB (Masih berkembang) berpindah menjadi BSH (Berkembang sesuai harapan), kriteria BSH (Berkembang sesuai harapan) berpindah menjadi BSB (berkembang sesuai harapan) sehingga pada siklus III semua anak sudah mencapai kriteria BSH (Berkembang sesuai harapan) dan kriteria BSB (Berkembang sangat Baik).

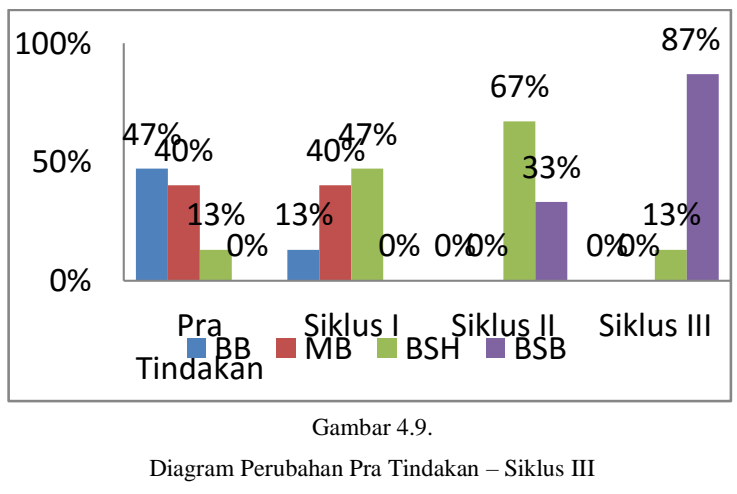

Aspek Melakukan Kegiatan Yang Menghasilkan Suatu Karya Seni

Dari gambar 4.6. dapat diketahui bahwa kriteria BB (belum berkembang) pada kondisi awal sebesar 47\% (7 orang anak), siklus I sebesar 13\% (2 orang anak), siklus II dan siklus III tidak ada satupun kriteria BB (Belum berkembang), Kriteria MB pada kondisi awal sebesar 40\% (6 orang anak), siklus I sebesar $40 \%$ (6 orang anak), siklus II dan III tidak ada satupun kriteria MB (Masih berkembang). Kriteria BSH (berkembang sesuai harapan) pada kondisi awal sebesar 13\% (2 orang anak), siklus I sebesar $47 \%$ (7 orang anak), siklus II sebesar $67 \%$ (10 orang anak), dan siklus III sebesar 13\% (2 orang anak). kriteria BSB (Berkembang sangat baik) pada kondisi awal dan siklus I tidak ada satupun kriteria BSB (Berkembang sangat baik), siklus II sebesar 33\% (5 orang anak), dan siklus III sebesar $87 \%$ (13 orang anak). Dari data tersebut kemampuan motorik halus anak usia dini pada aspek melakukan kegiatan yang menghasilkan suatu karya seni mengalami peningkatan. Hal tersebut terlihat dari perubahan tiap kriteria, dari BB (Belum berkembang) sebagian berpindah menjadi MB (Masih berkembang) meskipun masih ada anak yang kriteria BB (Belum berkembang), dari MB (Masih berkembang) berpindah menjadi BSH (Berkembang sesuai harapan), kriteria BSH (Berkembang sesuai harapan) berpindah menjadi BSB (berkembang sesuai harapan) sehingga pada siklus III semua anak sudah mencapai kriteria BSH (Berkembang sesuai harapan) dan kriteria BSB (Berkembang sangat Baik). 
Berdasarkan penelitian yang telah dilakukan dapat diketahui bahwa kegiatan kolase dapat meningkatkan kemampuan motorik halus anak usia dini, hal ini sejalan dengan penelitian skripsi Nur Halimah yang berjudul Peningkatan Kemampuan Motorik Halus Anak Usia Dini Melalui Kegiatan Kolase Dengan Berbagai Media Pada Anak Kelompok B3 di TK Aba Ngoro-oro Patuk Gunungkidul Tahun 2016. Kolase adalah aplikasi yang dibuat dengan menggabungkan teknik melukis (lukisan tangan) dengan menempelkan bahan-bahan tertentu sesuai dengan kebutuhan. Sesuai dengan Permendikbud Nomor 137 Tahun 2014 kegiatan yang dapat mengembangkan kemampuan motorik halus anak usia 5-6 tahun salah satunya adalah menempel. Jadi, dapat di tarik kesimpulan bahwa kegiatan kolase dapat meningkatan kemampuan motorik halus anak usia dini.

\section{KESIMPULAN}

Berdasarkan hasil penelitian dan temuan di lapangan tentang " Peningkatan Kemampuan Motorik Halus Anak Usia Dini melalui Kolase Berbahan Serbuk Kayu pada Kelompok B di RA Yasbiman Al-Munawar Kabupaten Tasikmalaya" dapat diperoleh kesimpulan sebagai berikut :

5.1 Perencanaan kegiatan peningkatan kemampuan motorik halus anak usia dini melalui kolase berbahan serbuk kayu pada kelompok B di RA Yasbiman AlMunawar, dengan memperhatikan petunjuk Penelitian Tindakan Kelas yang diberlakukan dan refleksi dari setiap siklus pembelajaran dapat meningkatkan kemampuan motorik halus anak usia dini pada kelompok B di RA Yasbiman AlMunawar.

5.2 Proses pembelajaran menggunakan kolase berbahan serbuk kayu ternyata dapat meningkatkan kemampuan guru dalam meningkatkan kemampuan motorik halus anak usia dini pada kelompok B di RA Yasbiman Al Munawar.
5.3 Peningkatan kemampuan motorik halus anak usia dini melalui kolase berbahan serbuk kayu di kelompok B RA Yasbiman Al-Munawar mengalami peningkatan.

\section{SARAN}

Dalam rangka meningkatkan kualitas dalam peningkatan kemampuan motorik halus anak usia dini, peneliti menyampaikan beberapa saran sebagai berikut.

5.1 Dalammelaksanakan kegiatan peningkatan motorik halus anak usia dini melalui kolase berbahan serbuk kayu hendaknya guru memilih pola gambar yang beragam dan serbuk kayu dengan warna yang beragam pula agar anak lebih antusias mengikuti kegiatan.

5.2 Bagi peneliti selanjutnya yang tertarik dengan penelitian peningkatan motorik halus anak usia dini sebaiknya menggunakan alternatif bahan yang lain atau dengan kegiatan yang lain yang lebih beragam.

\section{DAFTAR PUSTAKA}

Departemen Pertanian, Move Indonesia Pusat Pendidikan Lingkungan Hidup (PPLH). Tentang limbah kayu. 2017.

Devi, F. P. (2004). Peningkatan Kreativitas Melalui Kegiatan Kolase Pada Anak Kelompok B2 Di TK Aba Keringan Kecamatan Turi Kabupaten Sleman. (Skripsi, Universitas Negri Yogyakarta, diterbitkan)

Fauziyah, Fitriani. (2017). Penggunaan Media Kartu Kata Bergambar untuk Meningkatkan Penguasaan Kosakata Bahasa Sunda Anak Usia Dini Pada Kelompok B di TK PGRI Cibeureum. (Skripsi, Universitas Pendidikan Indonesia Kampus Tasikmalaya, 2016, tidak diterbitkan).

Hurloock, Elizabeth B. (1978). Perkembangan Anak. Jakarta : Penerbit Erlangga.

Indraswari, L. (2007). Peningkatan Perkembangan Motorik Halus Anak 
Usia Dini Melalui Kegiatan Mozaik di Taman Kanak-Kanak Pembina Agam. 2.

Kartini, E. (2016). Mengembangkan Motorik Halus melalui Teknik Meronce Untuk Anak Usia Dini . SKRIPSI, 5.

Mahardika, A. A. (2017). Kemampuan Motorik Halus. Bandung: Kresna Bina Insani Prima.

Mulyati, A. (2014). Peningkatan Keterampilan Motorik Halus Melalui Origami Pada Anak kelompok A TK Kusuma Baciro Gondokusuman Yogyakarta. Skripsi, 25.

Ndraha, Taliziduhu. (2013). Pengantar Teori Pengembangan Sumber Daya Manusia. Jakarta : Rineka Cipta

Simatupang, Dorlice dan Ema, Lady. (2015). Pengaruh Kegiatan Kolase terhadap Kecerdasan Visual Al-Spasial Usia 5-6 Tahun di RA Masjid Agung Medan. (Jurnal 2015 Universitas Negri Medan).

Slamet, Suyanto. (2005). Konsep Dasar Paud. Jakarta : Depdiknas

Soetjiningsih, Cristiana Hari. (2012). Perkembangan Anak Sejak Pembuahan Sampai Dengan Kanak-Kanak Akhir. Jakarta : PRENADA

Sujiono, Y. N. (2013). Konsep Dasar Anak Usia Dini. Jakarta: PT Indeks.

Sujiono Bambang, DKK. (2017). Metode Pengembangan Fisik. Bandung : Penerbit Universitas Terbuka

Sumantri.(2005) Model Pengembangan Keterampilan Motorik Anak Usia Dini. Jakarta: Departemen Pendidikan Nasional. Direktorat Jenderal Pendidikan Tinggi. Direktorat Pembinaan Pendidikan Tenaga Kependidikan Dan Ketenagaan Perguruan Tinggi. 